\title{
Notes on the Brazilian Brachycyrtus Kriechbaumer species (Hymenoptera, Ichneumonidae Brachycyrtinae)
}

\author{
Onody, HC.*, Loffredo, APS., Penteado-Dias, AM. \\ Departamento de Ecologia e Biologia Evolutiva, Universidade Federal de São Carlos - UFSCar, \\ CP 676, CEP 13565-905, São Carlos, SP, Brazil \\ *e-mail: helenaonody@yahoo.com.br \\ Received November 11, 2008 - Accepted November 26, 2008 - Distributed August 31, 2009
}

Brachycyrtus Kriechbaumer is the single genus of Brachycyrtinae Ichneumonidae subfamily, distributed through the tropics, but a few species can be found in the Neartic and Paleartic regions (Gauld and Ward, 2000). As far as is known, brachycyrtines are idiobionts ectoparasitoids of cocooned pupae and prepupae of Chrysopidae (Neuroptera), but biological information is very scarce.

Previously this group was known to belong to the Labeninae subfamily, but it was removed and elevated to sub-familial rank by Wahl (1993). Porter (1998) elevated Pedunculus Townes, 1969 to subfamily rank but later Gauld and Ward (2000) placed this genus with Adelphion and Monganella in the Pedunculinae subfamily and Brachycyrtus in Brachycyrtinae.

Only four among fifteen described species were recorded from Brazil: B. muesebecki (Walkley, 1956), B. cosmetus (Walkley, 1956), B. veriatrix Gauld and Ward, 2000 and B. walkleyae Gauld and Ward, 2000 (Walkley, 1956; Gauld and Ward, 2000; Yu et al., 2005).

Studying the material deposited in the DCBU collection of the Department of Ecology and Evolutionary Biology, Federal University of São Carlos, SP, Brazil from different localities, we have registered several new occurrence of species in Brazilian fauna of Ichneumonidae (Onody and Penteado-Dias, 2005; Loffredo and Penteado-Dias, 2008). To Brachycyrtus genus, seven species were found, being four, new records. Distribution information in different ecosystems and morphological notes are presented.

\section{Brachycyrtus cosmetus (Walkley 1956)}

Brachycyrtus cosmetus is a widely distributed species and, in Brazil, it was only known from the northern region. We have collected this species in many different ecosystems: caatinga, cerrado, wetlands of the pantanal and organic and conventional agricultural areas.

Variation: The Brazilian specimens presented an extensive range of colour variation, especially of the mesopleuron and legs.

Material examined - Brazil: Minas Gerais: Araporã, 4 + 31/i/2002, 25/iv/2002, 06/vi/2002, Malaise trap, C. H. Marchiori col.; São Paulo: Descalvado 4우,2万人 21/x/2000, 02/i/2002, 15/iii/2001, 1-21/x/2000, 06/iv/2001, Malaise trap, K.R.N. Cirelli col.; Mato
Grosso: Itiquira, 9우 $1 \lesssim$ 01/ix/1999, Malaise trap, M. Barros col., 23/x/2005, 13/i/2006, 20/i/2006, 03/ii/2006 06/v/2006, 30/xii/2005, Malaise trap, R.S. Santos col.; Paraíba: Patos,; 3ð̂, 8+17/vi/2004, 03/vi/2004, 15/vii/2004, 29/vii/2004, 12/viii/2004, Malaise trap, R.S. Santos col; São Paulo: São Carlos, 1 24/xi/1999, Malaise trap, A.M. Penteado-Dias col.

\section{Brachycyrtus oculatus Cushman 1936}

Brachycyrtus oculatus was only known from Costa Rica, Panama and Venezuela. In Brazil it was collected in the organic agricultural area of the Southeast region and in the Amazonian forest Material examined - Pará: Santarém 1 + 31/viii/1997, A.R. Lisboa col.; São Paulo: Araraquara $1 q$ 23.vi-07/vii. 2006, Malaise trap, H. C. Onody col.

\section{Brachycyrtus pretiosus Cushman 1936}

Brachycyrtus pretiosus was registered from the south of the United States to the north of Argentina. In Brazil, this species was collected in organic and conventional agricultural areas in the Southeast region.

Material examined - Brazil: São Paulo: Matão, $1 \delta$ 19/x/1999, Malaise trap, A.M. Penteado-Dias col.; Descalvado, 1 q,1 $\sigma^{\wedge}$ 15/iii/2000, Malaise trap, K. R.N. Cirelli col.; São Carlos, 3 + 12-26/viii/2005, Malaise trap, H.C. Onody. col; Araraquara, 2 2 23/vi-07/vii/2006, 21/vii-01/viii/2006, Malaise trap, H.C. Onody. col.

\section{Brachycyrtus veriatrix Gauld 2000}

The occurrence of Brachycyrtus veriatrix in Brazil was recorded only for the northern region. In this study it was collected in regions including organic and conventional agricultural areas, wetlands of the pantanal and cerrado.

Material examined - Brazil: Mato Grosso: Itiquira, $3 q 11 / x i / 2005, \quad 16 / x i i / 2005, \quad 06 / v i i / 1999$, 01/ix/1999, Malaise trap, M. M Barros, col; Minas Gerais: Araporã, 2థ09/v/2002, 15/viii/2002, Malaise trap, C. H. Marchiori col.; Pará: Santarém 1 9 15/i/1998, Malaise trap, A. R. Lisboa col.; São Paulo: Araraquara, 3이시 26/iv-10/v/2006, 26/v-09/vi/2006, 24/iii-04/ 
iv/2007, Malaise trap, H. C. Onody. col.; Descalvado, 1 ㅇ 15/iii/2000, Malaise trap, K.R.N. Cirelli col.

\section{Brachycyrtus walkleyae Gauld and Ward 2000}

This species was recorded only for the Northeast region of Brazil, in this study this species has been collected also in other areas of the Southeast and Northern regions.

Material examined - Brazil: Pará: Santarém 1 우 31/i/1999 A.R. Lisboa col.; São Paulo: Campos do Jordão 523/xi-10/xii/2001, 27/ix-12/x/2002, Malaise trap, S.A.G. Gomes col.; São Carlos 1 + 23/x/1997 A.M. Penteado-Dias col.

\section{Brachycyrtus xorix Gauld and Ward 2000}

This species was only known to occur in Costa Rica and Panamá. In Brazil one specimen was collected in the Brazilian Atlantic Forest.

Material examined - Brazil: Rio de Janeiro: Nova Iguaçu 1 ㅇ 5-8/iii/2002 S.T.P. Amarante e equipe col.

\section{Brachycyrtus zani Gauld and Ward 2000}

Brachycyrtus zani was known occurring in Costa Rica, Peru and Trinidad. Only one specimen was collected in the Southeast of Brazil.

Variation: The Brazilian specimen presented mesopleura without a black mark near the lower corner and metasoma with tergites II-III black, but posteriorly white and tergites II-VII with a straight division between the black and pallid areas.
Material examined - Brazil: Minas Gerais: Araporã 1 0 02/v/2002, H. H. Marchiori col..

Acknowledgements - The authors are grateful to $\mathrm{CNPq}$ (Conselho Nacional de Desenvolvimento Científico e Tecnológico) and FAPESP (Fundação de Apoio à pesquisa do Estado de São Paulo) for financial support.

\section{References}

GAULD, ID. and WARD, S. 2000. Subfamily Brachycyrtinae. In The Ichneumonidae of Costa Rica. Memoirs of the American Entomological Institute, vol. 63, p. 1-453.

LOFFREDO, APS. and PENTEADO-DIAS, AM. 2008. First record of Schyzopyga Gravenhorst (Hymenoptera, Ichneumonidae, Pimplinae) from Brazil and a description of a new species. Revista Brasileira de Biologia $=$ Brazilian Journal of Biology, vol. 68, no. 2, p. 457-458.

ONODY, HC and PENTEADO-DIAS, AM. 2005. Novos dados de ocorrência de oito espécies de Ophioninae (Hymenoptera: Ichneumonidae) no Brasil. Entomotropica, vol. 2, no 1, p. $71-74$.

PORTER, CC. 1998. Guía de los géneros de Ichneumonidae en la región neantárctica del sur de Sudamérica. Opera Lilloana, vol. 42, p. 1-234.

WAHL, DB. 1993. Cladistics of the genera of Labeninae (Hymenoptera: Ichneumonidae). Entomologia Generalis, vol. 18 , p. 91-105.

WALKLEY, LM. 1956. A tribal revision of the Brachycyrtinae wasps of the world (Cryptinae- Ichneumonidae). Proceedings of the United States National Museum, vol. 106, p. 315-329.

YU, DS. 2005. Taxapad Ichneumonoidea. Vancouver, Canada: [s.n.]. Available from: <http://www.taxapad.com>. 